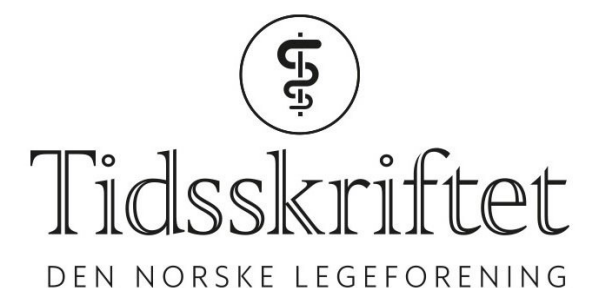

DEN NORSKE LEGEFORENING

\title{
Valg av protese ved lårhalsbrudd
}

LEDER

\section{TORBJØRN BERGE KRISTENSEN}

E-post: torbjorn.berge.kristensen@helse-bergen.no

Torbjørn Berge Kristensen er ph.d. og overlege ved Ortopedisk avdeling, Haukeland universitetssjukehus.

Forfatteren har fylt ut ICMJE-skjemaet og oppgir ingen interessekonflikter.

\section{JAN-ERIK GJERTSEN}

Jan-Erik Gjertsen er ph.d. og overlege ved Ortopedisk avdeling, Haukeland universitetssjukehus og førsteamanuensis ved Klinisk institutt 1, Universitetet i Bergen. Han er leder for Nasjonalt hoftebruddregister.

Forfatteren har fylt ut ICMJE-skjemaet og oppgir ingen interessekonflikter.

Riktig protese gir færre reoperasjoner. Pasientene er skrøpelige, og en reoperasjon er forbundet med høy dødelighet.

Årlig opereres rundt 3500 pasienter med hemiprotese for lårhalsbrudd ved norske sykehus. Pasientgruppen har en gjennomsnittsalder på over 80 år og høy forekomst av benskjørhet og andre tilleggssykdommer (1). Flesteparten oppnår ikke det funksjonsnivået eller den livskvaliteten som de hadde før bruddet inntraff, og én av fire pasienter dør innen ett år (2). Mens lårhalsbrudd ute av stilling tidligere ble operert med skruefiksasjon, opereres nå nesten alle med protese, fordi flere studier har vist bedre livskvalitet, bedre hoftefunksjon og færre reoperasjoner ved bruk av protese sammenlignet med skruefiksasjon. De vanligste reoperasjonsårsakene etter protesekirurgi er infeksjon, at protesen går ut av ledd og protesenære brudd (1).

Et protesenært brudd er en sjelden, men alvorlig komplikasjon. I noen tilfeller hvor protesen sitter fast og bruddet er stabilt, kan et slikt brudd behandles uten ny kirurgi, men vil ofte innebære smerter, immobilisering og dårligere hoftefunksjon. I de fleste tilfeller er imidlertid et nytt og omfattende kirurgisk inngrep nødvendig, enten osteosyntese med en lang metallplate på lårbenskaftet eller utskifting av hele protesen (3). Slik kirurgi kan føre til stort blodtap, tromboserisiko, smerter, nedsatt hoftefunksjon samt langvarig rehabilitering. En reoperasjon er forbundet med redusert funksjonsnivå, høy morbiditet og høy mortalitet (4-6).

Innleggelse fra sykehjem, mannlig kjønn og alder over 9o år er ikke-påvirkbare faktorer forbundet med en dårligere prognose og økt mortalitet hos hoftebruddpasienter (7). Andre faktorer lar seg derimot påvirke, slik som valg av operasjonsmetode og protese.

Man bør differensiere behandlingen og velge en protese med rett eller anatomisk sementert stamme til hoftebruddpasienter med dårlig benkvalitet

I tråd med internasjonale studier viser studier med data fra Nasjonalt hoftebruddregister 
(8) økt risiko for reoperasjon grunnet protesenære brudd ved bruk av usementerte protesestammer sammenlignet med sementerte stammer. I de nasjonale retningslinjene anbefales derfor bruk av sementerte lårbensproteser til alle pasienter med akutt lårhalsbrudd som er ute av stilling (9). Likevel er det flere sykehus som fortsatt bruker usementerte protesestammer.

Videre er det forskjellige design på de sementerte protesestammene som blir benyttet $\mathrm{i}$ Norge. Protesenære brudd oppstår nesten utelukkende ved bruk av protesestammer som er glatte og kileformede, og sjelden ved bruk av rette og anatomiske protesestammer med matt overflate $(10,11)$. Glatte kileformede stammer har vært de mest brukte protesene i Norge de siste årene (1), og de har svært gode resultater i studier av yngre artrosepasienter med god benkvalitet. Hos eldre hoftebruddpasienter med dårlig benkvalitet gir de dessverre $\varnothing$ ket risiko for protesenære brudd.

Hvilken protesetype som skal benyttes, har tradisjonelt vært bestemt på sykehusnivå etter en anbudsprosess. Anbudet danner grunnlaget for hvilken behandling som tilbys og hvilke resultater som kan oppnås. Det har vært vanlig at sykehus har valgt én protesetype uavhengig av om operasjonen er for artrose eller hoftebrudd. I tråd med internasjonale og norske studier bør man differensiere behandlingen og velge en protese med rett eller anatomisk sementert stamme til hoftebruddpasienter med dårlig benkvalitet. Hoftebruddpasienter utgjør en eldre og skrøpelig pasientgruppe som fortjener den best dokumenterte behandlingen uavhengig av hvilket sykehus pasienten tilhører.

\section{LITTERATUR:}

1. Årsrapport. Juni 2019. Bergen: Nasjonal kompetansetjeneste for leddproteser og hoftebrudd, 2019. http://nrlweb.ihelse.net/Rapporter/Rapport2019.pdf Lest 29.1.2020.

2. Parker M, Johansen A. Hip fracture. BMJ 2006; 333: 27-30. [PubMed][CrossRef]

3. Yasen AT, Haddad FS. Periprosthetic fractures: bespoke solutions. Bone Joint J 2014; 96-B (suppl A): 48-55. [PubMed][CrossRef]

4. Svenøy S, Westberg M, Figved W et al. Posterior versus lateral approach for hemiarthroplasty after femoral neck fracture: Early complications in a prospective cohort of 583 patients. Injury 2017; 48 : 1565-9. [PubMed][CrossRef]

5. Guren E, Figved W, Frihagen F et al. Prosthetic joint infection-a devastating complication of hemiarthroplasty for hip fracture. Acta Orthop 2017; 88:383-9. [PubMed][CrossRef]

6. Phillips JR, Moran CG, Manktelow AR. Periprosthetic fractures around hip hemiarthroplasty performed for hip fracture. Injury 2013; 44: 757-62. [PubMed][CrossRef]

7. Bhandari M, Koo H, Saunders L et al. Predictors of in-hospital mortality following operative management of hip fractures. Int J Surg Investig 1999; 1:319-26. [PubMed]

8. Kristensen TB, Dybvik E, Kristoffersen M et al. Cemented or uncemented hemiarthroplasty for femoral neck fracture? Data from the Norwegian Hip Fracture Register. Clin Orthop Relat Res 2020; 478: 90-100. [PubMed][CrossRef]

9. Norske retningslinjer for tverrfaglig behandling av hoftebrudd. Oslo: Den norske legeforening, 2018.

http://nrlweb.ihelse.net/Anbefalinger/Norske\%2oretningslinjer\%2ofor\%2otverrfaglig\%2obehandling\%2 oav\%2ohoftebrudd.pdf Lest 29.1.2020.

10. Kristensen TB, Dybvik E, Furnes O et al. More reoperations for periprosthetic fracture after cemented hemiarthroplasty with polished taper-slip stems than after anatomical and straight stems in the treatment of hip fractures: a study from the Norwegian Hip Fracture Register 2005 to 2016. Bone Joint J 2018; 100-B: 1565-71. [PubMed][CrossRef]

11. Mohammed J, Mukka S, Hedbeck CJ et al. Reduced periprosthetic fracture rate when changing from a tapered polished stem to an anatomical stem for cemented hip arthroplasty: an observational prospective cohort study with a follow-up of 2 years. Acta Orthop 2019; 90: 427-32. [PubMed][CrossRef] 
Publisert: 9. mars 2020. Tidsskr Nor Legeforen. DOI:10.4045/tidsskr.19.0805

(C) Tidsskrift for Den norske legeforening 2020. Lastet ned fra tidsskriftet.no 